\title{
Child's Privacy Jurisprudence and International Instruments
}

\author{
Zahra Ansari ${ }^{1}$, Mohammad Bahrami Khoshkar ${ }^{2} \&$ Mohammad Ebadi ${ }^{1}$ \\ ${ }^{1}$ Department of Humanities, Islamic Law and Jurisprudence, Islamic Azad University, Iran \\ ${ }^{2}$ Associate Professor of University of Motahari, Faculty of Humanities, Iran \\ Correspondence: Zahra Ansari, Department of Humanities, Islamic Law and Jurisprudence, Islamic Azad \\ University, Iran.
}

Received: May 11, 2016 Accepted: July 12, 2016 Online Published: August 30, 2016

doi:10.5539/jpl.v9n7p128 URL: http://dx.doi.org/10.5539/jpl.v9n7p128

\begin{abstract}
In the privacy rights of Shiite jurisprudence Iran directly noted instances of its use of the term is limited including the need to protect the privacy of the place with the explicit text of the Holy Quran. It's important to enter the house without letting others do not the civil rights of the Islamic Republic of Iran, which is Shiite jurisprudence emanating from pointed to some evidences of privacy. But in international documents under human rights law and conventions of privacy have been more effectively different categories of persons referred to in the privacy in Shiite jurisprudence and civil rights and the fundamental rights of the Islamic Republic of Iran. However, also examples of human beings considered independently about the child's privacy is something not stated. Although, due to the arrival of children, especially in social virtual communities appear to need immediate attention to children's privacy by lawyers. The drafters of civil law is necessary and international measures to develop laws in this case was conducted including raising the age to 16 years joined children to social networks can be mentioned which is also protect the privacy of physical and sexual children abuse. All psychologists' attention and extreme caution is ding to conflicts. According to the children defenseless against this social problem that should be subject to specific and severe punishment for properties compared with adults who are physically punished are more defense capabilities and reason legislators should be.
\end{abstract}

Keywords: international instruments, jurisprudence, location privacy, child's privacy

\section{Introduction}

One of the most important privacy rights of every human being and maintain it. Privacy man as he is considered a value for human dignity is inviolable. The child is also as an individual's person as well as individual privacy is capable of human benefit. The moral and religious teachings of Islam incessantly talk directly privacy has not been raised, but with recommendations concerning the issues of privacy, such as the lack of surveillance in private life or dignity of a person's privacy intrusion another location, and the child is raised in this regard recommended general considered sufficient for the child and the issue is not addressed in this regard. In the Islamic Republic of Iran laws of any particular approach in this regard cannot be found to demonstrate the laws of the child's rights to privacy standards and determine its violation is incomplete. From the perspective of the International Convention on the Rights of the Child as the most significant set of laws regarding the rights of the child considering the possibility of intervention by law, necessary in the best interests of the child right to education priorities on children's right to privacy the way for the Protection of Children's and training children's breeding.

\subsection{Privacy in Jurisprudence of Islam}

Defined Harim as an privacy in the place searched to protect and defend it is necessary to have meaning (Moeen in 2003) and what is forbidden to hand it to where it cannot be reached (Dehkhoda, 1997). Arabic privacy of origin (shrine) is meant to prevent and also, privacy various constraints underlying the ban and prohibition. Including Harim prohibited, anything that touches it is forbidden and banned (Ibn Babaoyeh, 1404 AH: 237) including the use of the word Harim in the interpretation of legal sources privacy. People's privacy is mentioned in legal sources, such as banning surveillance, inspection, suspicion, eavesdropping, absenteeism, for accusing and enters homes without permission of other people (Ansari, the 66 four4). In other words, the scope of the entry of privacy or personal life of each human being is considered. 


\subsection{Classification of Titles Privacy}

This range can be divided into 2 general ways: First is Harim and spiritual range and second is Harim and material range. Of course, many sociologists categorized the person's privacy to national privacy, social privacy, family privacy, individual privacy.

\subsection{Privacy Commitment and Harmless Principles in Jurisprudence}

Commitment of Harim in Islam jurisprudence and individual's privacy is "harmless principles". Documentation of harmless principles leaded to some spiritual damage, which is one of human dignity or credit persons through the violation of the privacy family be molested, that includes the harmless principles. The harmless principle is one of the most important rules that could protect the dignity, honor, reputation, social grandeur persons.

\subsection{Jurisprudence Requirements of Privacy (Privacy Material)}

While legal systems at most a few centuries before Islam and revelations have been given the right to privacy is more than 1,400 years and thereby, signifying the superior value and position for human dignity. In verses 27 and 28 of Surah Al-Nur respect the privacy aspect is explicitly mentioned: The people who believe are never enter the house other than your houses unless you are the owner of the friend and do not enter the house if they do not familiar, and also, if someone was not there, do not enter without permission. When you come back and say that this is a sign of purity after your return and the LORD informed and wise whatever you do. Also, in verse 11 of Surah cells Allah says: people who have believed, to fear of suspicion about each other's because some suspicions are sin and also, never search each other and do not gossip. Are you someone who likes to eat the flesh of his dead brother? Of course, this is disgusting hate and should fear Allah, so that he is the relenting and the merciful. Location, ownership, right to the enjoyment of the presumption of innocence is included.

\section{Privacy in the Islamic Republic of Iran}

\subsection{Privacy Basic Rules Iran}

In basic rules Iranian law, the privacy is unprecedented. Determination of its territory can be said by Iranian lawmakers from the beginning of the legislative examples of respect for the right to be considered.

Constitutional law on the rights of the nation's constitution adopted in 1945 three principles, it is necessary to respect the privacy and sanctity of the home originally to house its thirteenth and twenty-second principles reserved postal correspondence, discovery and recording of the twenty-third of the ban on disclosure detention of telegraphic notes (official newspaper 1388: 5). Implementation of this principle in relation to the new technologies of communication and intelligence on cyber crimes law enacted 20/2/2009 is considered. Principle 22 of the constitution states that "reputation, life, property, rights, residence and occupation of the individual are inviolate, except in cases approved by law", and also, personal's privacy and individual's security are considered inviolable.

\subsection{Privacy in Civil Law}

In civil law in many substances, including principles $97,98,100,102,104,106,130,133$ and 139. In cases of privacy, it's merely "about the privacy of the property's contents to other law of issues of privacy is not mentioned.

\subsection{Privacy International Documents}

The right to privacy is well expressed in international law. According to declaration of human rights and principle 12 which is expressly to the personal privacy that in relation to the same issues in the International Convention of Civil Rights and Europe Convention was proposed and confirmed. In some of the contracts, conventions about personal privacy will be referred.

1) The Universal Declaration of Human Rights states in principle 3: Everyone has the right to life, liberty and security of person. In principle 12 of the declaration also says: no privacy, family, home or correspondence, nobody arbitrary intervention for or take the dignity and reputation of someone's attack. The intervention of the law on the right of every person.

2) The Europe Council has issued a resolution about the privacy of your privacy as a right to a life with your own taste and defined by minimum intervention. Lawyers conference on the right to privacy which was held in Norway in paragraph 2 of its declaration has the right to privacy is a right to be left alone, to live up to your own taste with the least intervention of others.

3) The Declaration of Islamic Human Rights adopted by 14 Muharram 1411 AH in Cairo in principle 18 section

(b) in the context of respect for privacy has created every human being is entitled to in their private lives 
independence and spying or monitor him and distorted reputation, he is not allowed and must be protected against any coercive intervention.

4) According to the privacy statement of principles summit on the information society summit approved September 12, 2003 can be seen. In principle 35, the statement said strengthened framework ensuring the security of information, including credit guarantee network security, privacy and protection of consumer society creates preconditions and building trust between the use of information and communication technologies is information.

In principle 58, the statement in the use of information technologies, human rights and fundamental freedoms, including privacy is emphasized (article, site of the Judiciary of the Islamic Republic of Iran, privacy and human rights in international documents).

\section{The Concept of Childhood in Islamic Jurisprudence and International Instruments}

\subsection{The Definition of Child Perspective of Islamic Jurisprudence}

In Jurisprudence book, to leave children changed to the adult criteria listed signs and symptoms of these criteria which are not created; it means that the person is still a child. Such as cosmetic changes, poetry proof and autoerotism ... (Martyr Thani, 1409 AH: 267).

\subsection{The Definition of a Child from the Perspective of the Islamic Republic of Iran}

In clause 1 of principle 49 is provided by $\mathrm{BC}$ law usually argue the purpose of the child who has not reached the level of maturity based on religious puberty, clause 1 principle 1210 of Hegira. D. For boys and girls entire 15 and 9 years, respectively.

\subsection{Defined Age from the Perspective of the CRC}

In the declaration of the rights of the child act of 1924 and the beginning of the end of 1925 did not mention. However, according to principle 1 of the CRC, a child "every human being below 18 years is" the definition of a child as a result of that distance in the Iranian legal documents and international instruments for the boys and girls at least 3 years and 9 years, respectively. And this remarkable challenge in defining their behavior in accordance with international and domestic documents creates.

\section{Children's Rights in Iran Domestic Rules and International Instruments}

Children's rights at an overall look can be divided into two parts: the first- children to be human rights, children's rights and second- Children's right containing to be "child". Containing to be human: children ranging from individual rights, economic and social in the same rights adults. The enjoyment of the right to life is the most important and fundamental right of every human right to health as well as physical health of children and adults are no different (Martyr Thani, 1419 AH, 373). And from being a child to an interim law that will change the character upon maturity of the individual rights such as custody rights (maintenance and training for children), the right to proper nutrition, the right to education and etc. From a careful analysis of the expression, including in the fields of: inheritance, range, nemesis, marriage, divorce, and guardianship (Najafi, 1981: 222).

\subsection{Children's Rights in Iran}

Rules in principle 21 of the Islamic Republic of Iran's constitution to protect the rights of children referred to children's rights also, many instances of criminal laws and legal materials based Iran jurisprudence is considered popular vote. Protect the rights of children referred to Children's Rights, also many instances of criminal laws and legal materials based Iran jurisprudence is considered popular vote. Principles 1168 to 1179 of the Civil Code of the most important examples custody of children is explicitly stated. (Imam, 1358: 201).

\subsection{Children's Rights in the International Instruments}

In the case of international instruments, the importance of the role of children has been increasing attention to them. In a few decades earlier summit or not many of the documents implicitly or independent human rights children have rights. And for children's higher interests, duties and obligations on governments and families left. Among the Universal Declaration of Human Rights (1948), the International Covenant on Economic - Social and cultural (1966), the International Covenant on Civil and Political Rights (1966) Islamic Declaration of Human Rights (1999) and the Millennium Declaration United Nations, while the various topics have also raised the rights of the child.

On the other hand, there are documents that are generally related to children's rights, including the Universal Declaration of Rights of the Child (1959), the United Nations Minimum Rules for the Administration of favorable special hearing of juvenile (Beijing Rules, 1958) and regulations of the United Nations for support of 
juveniles deprived of freedoms (1990).

The most important document about Children International Convention Rights of the Child adopted by the United Nations Universal Convention on 20 November 1989 entered into force on 2 September 1990. As well as, the two optional protocol, one on the sale of child prostitution and child pornography (adopted by the Universal Convention of the United Nations, the May 2000 and entered into force on 18 January 2002) and another on the use of children in armed conflict (adopted by the Universal Convention United Nations 25 may 2000 and entered into force 12 February 2002). (International Congress of religious thoughts Culture, 1393).

\section{Working Family Upbringing in Understanding the Privacy of the Child}

First, it works to teach them if, he understands the concept of privacy for himself and the other children from birth sees education call it their own. His father's and mother's have her own toothbrush and privacy. This way the child can distinguish between himself and others in this case.

Second, understand the concept of privacy for children: strange and familiar for children other than parents, brother and sister, who they can see children, hug him and give him gift and meal. Thus, they can feel the balance of the stranger and familiar. Third, understand the concept of privacy to children in the family the first concepts of borders and distance. However, boundaries private Harim closes the role in the child's mind: Everyone should sleep in his own bed, have a shower, everyone will have to wait until others bathrooms come out, when sitting on the sofa should not be too attached to others, when the painting should protrudes from the line.

Third, understand the concept of privacy for children and telling their secrets: children must learn to keep the secret of house at home and not told anywhere else. But, we also need to learn outdoors events, such as kindergartens or schools should be told at home .Children the catcher must know that sometimes there are many things that should not be told and who should remain a mystery.

Forth, understand the concept of privacy for children: the concept of honor and house rules when the child understands and other places at different times, in order to understand the value reaches superior. Some of the more valuable, more work they need to protect their ratio to be in charge.

Fifth, in understanding the concept of privacy for children: Children should learn to interfere or meddle by adult supervision from concept to separate the affairs of others.

\subsection{How Parents Manage Child Sexual Characteristics (Physical Privacy)}

Most of this confusion perspective of parents to the children about sexual issues. Questions their children to their internal and external world with curiosity toward adulthood is different psychosexual implications .Children are not regard it as adults to their own beliefs in this regard. When parents talk with their children about sexuality private word and secret should not talk to them.

Several solutions about the privacy of child sex:

1) Do not punishment the children for sexual question and behavior.

2) Do not leave the answers to the future of your children and do not benign confusing messages and their shame. Also, control your anxiety in this field and never use the words "When you grow up you will understand", "these issues related to adults"," this is word is hideous" (Akbari Haghighat, the same).

\section{Children's Privacy in Cyberspace}

With the development of the internet public access to data processors in the virtual space has increased. Meanwhile, children have accounted for a significant share. An inherent right to privacy per ounce and children as well as individual human beings is subject to the inherent right. People in general and children in particular rules state support and legal protection of these rights within your child can benefit. Concerns about the safety of children and adolescents has increased their building, before decisions need to be taken advantage of possible causal new legislation in Europe in order to increase the minimum age for children allowed to attend social networks from 13 years to 16 years later in 2015 represents. In other countries, there are concerns about children's use of social networking which in summary, the main purpose is children's privacy protection laws so that parents control over information collected from children will have and how to use them.

\section{Results}

Privacy for every human being has an inherent right of the human person and children as well as be subject to the inherent right. Children due to its nature requires the necessary training on these skills and gaining their inherent right is that most parents know the rules provide the necessary task. The statutes of international and 
domestic laws and jurisprudence for the natural right of people in general and children in particular, imposed protectionist laws. In particular, the rules state support and legal protection of these rights in the context of your child can benefit. One reason for the vulnerability of children to understand the importance of privacy and awareness of issues surrounding it. Due to the susceptibility of the need to work with the right training to children and informing them of the risks. Also, determination of regulations and laws on children's privacy can support them in the field as much as possible.

\section{References}

Akbari, H. (n.d.). The doctor said and psychology encyclopedia article, the child's world.

Ansari, B. (n.d.). paper, privacy and protection of the rights of Islam. Journal of Law and Political Science, Tehran University, 66(4).

Babawayh, I., \& La Yhzrh I. (1404 AH). Al-Bayt Publications. Qom.

Emami, F. (1358). Civil rights F. C 5, Islamic Publications, Tehran.

Evening, A. M. B., \& Al-Anwar, B. Al-Imamiya Daralktab Press, 93(257).

Ghanavati, J., \& Ahmed., H. (1392). Journal of Legal Studies (2nd ed.). University of Shiraz.

Modal, M. (1392). Persian culture specific, Amir Kabir Publications, published twenty-seventh.

Mousavi, S. M. (n.d.). Place children in Islamic jurisprudence thoughts international documents, the International Congress of Religious Culture thoughts.

Najafi, M. H., \& Ibn al-Baqir. (1981). Javaheri Kalam fi Alshray as al-Islam, F Beirut 21(222).

Pour Abdollah, C. A Faculty Member at the University of Imam Sadeq (AS) on the Judicial Organization of the Armed Forces.

Tabatabai, E, Thematic encyclopedia, published by Ahl al-Bayt (AS) article, the family of the Quran.

Vice prevent crime, the judiciary, the Conference of Applied Sciences, Tehran, Press and Publication Centre judiciary first published in 1383 .

Zainuddin, B. A. (1419 AH). The martyr Thani, masalek Alafham to Tnqy religions-Islam, Qom, Vol. 8, Page 373.

Zainuddin, B. A. The martyr Thani, Alrvzh Albhyh Fi as Almhdmshqyh, 7(68).

\section{Copyrights}

Copyright for this article is retained by the author(s), with first publication rights granted to the journal.

This is an open-access article distributed under the terms and conditions of the Creative Commons Attribution license (http://creativecommons.org/licenses/by/4.0/). 